\title{
Adapting date palm offshoots to long-term irrigation using groundwater in sandy soil
}

\author{
Hussein J. Shareef ${ }^{*}$, Abdulrahman S. Alhamd ${ }^{1}$, Summar A. Naqvi ${ }^{2}$, \\ Mamdouh A. Eissa ${ }^{3}$ \\ 'Department of Date Palm Research Center, University of Basrah, Basrah, 00964, Iraq \\ ${ }^{2}$ Institute of Horticultural Sciences, University of Agriculture, Faisalabad, Pakistan \\ ${ }^{3}$ Department of Soils and Water, Faculty of Agriculture, Assiut University, \\ Assiut, 00962, Egypt
}

\begin{abstract}
Shareef, H.J., Alhamd, A.S., Naqvi, S.A., Eissa, M.A., 2021. Adapting date palm offshoots to long-term irrigation using groundwater in sandy soil. Folia Oecologica, 48 (1): 55-62.

The date palm can grow in desert areas using high salinity groundwater by increasing the number of irrigation cycles. A field experiment was carried out on date palm cv. Sayer offshoots grown in sandy saline soil during the 2017 and 2018 growing seasons. The outcomes demonstrated that the application of saline $\left(10 \mathrm{dS} \mathrm{m}^{-1}\right)$ groundwater every four days increased plant height, number of new leaves, total chlorophyll, and relative water content. In turn, the hydrogen peroxide, malondialdehyde, and electrolyte leakage were reduced. Also, the effect of this treatment improved the growth of the plants, thus reduced the absorption of sodium, chloride, and increased potassium, then decreased the $\mathrm{Na} / \mathrm{K}$ ratio. Cluster analysis showed two distinct cluster groups. In the first group, the dissimilarity between the treatments is illustrated by the influence of freshwater. While the second group showed the similarity between the treatments of four days and every week in the subgroup. Whereas treatment of two weeks duration shows the most detrimental effect on growth indices and chemical properties of offshoots. The utilization of saline groundwater in the water system of the date palm is the best option among the solutions possible in the current conditions of drought and thermal retention.
\end{abstract}

\section{Keywords}

groundwater, hydrogen peroxide, lipid peroxidation, water system cycles

\section{Introduction}

The world is suffering from two major problems: the growing demand for food and climate change. Date palms (Phoenix dactylifera L.) provide solutions to these problems through their high production to solve the first problem, which enters several food industries and their ability to withstand harsh environmental conditions, to solve the second problem. Date palm trees improve the atmosphere by converting carbon dioxide to carbohydrates and oxygen at a higher rate than other plants (SHARIF et al., 2010). Thus, the expansion of date palm cultivation can contribute to reducing the impact of climate change. Sayer cultivar is a medium salt-tolerant cultivar with rapid growth (ABBAs et al., 2015). Irrigation requirements of date palm vary depending on location, surrounding environment, and irrigation methods used (IsMaIL et al., 2014). Each date palm's requirement in the irrigation system is $150-200 \mathrm{~m}^{3}$ year-1 from water for growth and yield (Allbed et al., 2017).

In arid and semiarid areas, those interested in date palm are facing the reality of scarcity of irrigation water

\footnotetext{
*Corresponding author: e-mail: hussein.shareef@uobasrah.edu.iq
} 
and meeting the plant's need for large quantities of water. The expanding competition for water assets, although the shortage of resources with the accessibility of water wells, has led to the use of low-quality water for agriculture (Al Omron et al., 2012). Applying groundwater to irrigate date palm, which is considered to have the most noteworthy salt tolerance of all fruit plants, is feasible with a few varieties adapted to salinity readings of up to $13 \mathrm{dS}$ $\mathrm{m}^{-1}$ (RAmoliya and Pandey, 2003). Whereas other types can endure up to $32 \mathrm{dS} \mathrm{m}^{-1}$ (ABBAS et al., 2015); however, excess saltiness can cause a considerable lessening in yield (BEN-GAL et al., 2008). Also, the salinity experiments by ALRASBI et al. (2010) showed a decrease in growth parameters in date palm in electrical conductivity (EC) $18 \mathrm{dS} \mathrm{m}^{-1}$. Moreover, it was recommended to use saline water to irrigate vegetative growth of date palm. In this way, regions with soil salinity of $4-16 \mathrm{dS} \mathrm{m}^{-1}$ are viewed as acceptable. In contrast, areas with soil salinity above 16 $\mathrm{dS} \mathrm{m}{ }^{-1}$ are considered inadequate (ALLBED et al., 2017).

The indicators of plant adaptation for saline stress are improved plant growth, lower tissue content of toxic concentrations of some elements such as chlorine and sodium, high potassium, in addition to improvement in photosynthesis by increasing total chlorophyll in the leaves of the plant (ZHANG et al., 2008; SHAREEF et al., 2020). The most critical organs of the plant in contact with the soil and determining the survival of the plant are the roots (PAL et al., 2010). The rhizosphere zone and water system are essential variables for increasing or decreasing the growth of date palm under high salinity (AL KHARUSI et al., 2017). The most severe damage a plant can experience from the effect of high salinity is oxidative stress; oxidative stress is an imbalance in the metabolic output of reactive oxygen species (ROS) and antioxidant substances; increased ROS production causes increased accumulation of hydrogen peroxide, lipid peroxidation and membrane permeability (ABDELGAWAD et al., 2016).

Today, date palm offshoots and seeds are planted in sandy soil in many parts of the world (Iraq, Saudi Arabia, Oman, and other North African countries), due to several reasons, including urban expansion at the expense of green areas, creating green belts for cities to reduce dust storms, or to get rid of pest infestation areas that are active in coastal areas. A surface irrigation system with groundwater is usually used in these areas. However, there are no data on agricultural land that receive irrigation from water wells. Consequently, the motive behind this experiment is to examine the effect of irrigation using well water on the adaptation of date palm to salinity as observed through certain growth indicators.

\section{Materials and methods}

\section{Practical experiment}

The experiment was executed at a single orchard in the Al-Zubair region - Basrah, Iraq (30.285504, 47.694871), $26 \mathrm{~km}$ from Basrah center, during the 2017 and 2018 growing seasons. Forty uniform trees, 4-5 years, of cv. Sayer offshoots were used in this experiment. The date palm plants received standard cultural practices, a substrate of sandy loam soil, and watered by the surface irrigation method. The selected offshoots were planted at $7 \times 7 \mathrm{~m}$ spacing. The regular EC of water $\left(10 \mathrm{dS} \mathrm{m}^{-1}\right.$, $\mathrm{pH} 7.10$ ) used well water. Soil characteristics are shown in Table 1. Each plant received treatment on 1 March 2017 and continued until the samples were examined on 1 November 2018, with two plants for each replicate and five replicate for each treatment. The offshoots were exposed to the application of groundwater as follows: control irrigation with freshwater (EC $1.5 \mathrm{dS} \mathrm{m}^{-1}$ ) every four days (Co). Irrigation with groundwater was every four days (W1); irrigation with groundwater every week (W2); irrigation with groundwater every two weeks (W3). The data collected on 1 November 2018.

\section{Growth parameters}

Plant height was determined by tape measure to the third completely extended leaf. New leaf number of offshoots was measured by applying the equation: New leaves

Table 1. Characteristics of the soil sites

\begin{tabular}{ccc}
\hline Soil characteristics & Units & Values \\
\hline $\mathrm{pH}$ & - & 7.92 \\
Electrical conductivity (EC) & $\mathrm{dS} \mathrm{m}^{-1}$ & 12 \\
Nitrogen & $\mathrm{mg} \mathrm{kg}^{-1}$ & 0.33 \\
Potassium & $\mathrm{mg} \mathrm{kg}^{-1}$ & 80.00 \\
Phosphor & $\mathrm{mg} \mathrm{kg}^{-1}$ & 10.70 \\
$\mathrm{HCO}_{3-}$ & $\mathrm{ml} \mathrm{l}^{-1}$ & 2.7 \\
Organic carbon & $\mathrm{g} \mathrm{kg}^{-1}$ & 3.05 \\
Organic matter & $\mathrm{g} \mathrm{kg} \mathrm{k}^{-1}$ & 0.34 \\
\hline
\end{tabular}


number $=$ Total of leaves on 1 November $2018-$ Total of leaves before treatment (28 February 2017).

Total chlorophyll extracted as clarified by Lichtenthaler and WeLlburn (1983), the leaf (0.25 g) homogenized with $80 \%$ acetone the optical thickness of the removed chlorophyll estimated at 645 and $663 \mathrm{~nm}$ by utilizing spectrophotometer. Leaf tests weighed (new biomass) quickly after accumulation, absorbed pure water at $25^{\circ} \mathrm{C}$ for $24 \mathrm{~h}$, by then, the sample dried in an oven at $80^{\circ} \mathrm{C}$ for $48 \mathrm{~h}$, and their shriveled biomass was collected. Relative water content (RWC\%) was measured by the equation: $\mathrm{RWC} \%=($ fresh mass $(\mathrm{g})-$ dry mass $(\mathrm{g}))$ / (turgid mass $(\mathrm{g})-$ dry mass $(\mathrm{g})) \times 100$.

\section{Hydrogen peroxide}

Hydrogen peroxide was examined using the technique described by $\mathrm{Yu}$ et al. (2003). $\mathrm{H}_{2} \mathrm{O}_{2}$ separated by crushing $0.5 \mathrm{~g}$ of leaf tissue with $3 \mathrm{ml}$ of $50 \mathrm{mM} \mathrm{K}$-phosphate buffer $\mathrm{pH}(6.5)$ at $4{ }^{\circ} \mathrm{C}$. The mixture centrifuged at $2,415 \mathrm{x}$ g for $15 \mathrm{~min}$. A $3 \mathrm{ml}$ test of the supernatant mixture with $1 \mathrm{ml}$ of $0.1 \% \mathrm{TiCl}_{4}$ in $2 \mathrm{M} \mathrm{H}_{2} \mathrm{SO}_{4}(\mathrm{v} / \mathrm{v})$ and the combination centrifuged at $2,000 \mathrm{x}$ for $15 \mathrm{~min}$. The optical maintenance of the supernatant was evaluated at $410 \mathrm{~nm}$ to choose the $\mathrm{H}_{2} \mathrm{O}_{2}$ content and imparted as $\mu \mathrm{mol} \mathrm{g} \mathrm{g}^{-1} \mathrm{FW}$.

\section{Lipid peroxidation}

Lipid peroxidation was controlled by evaluating the malondialdehyde (MDA) content in $1 \mathrm{~g}$ leaf crisp load, as indicated by MADHAVARAo and SRESTY (2000). MDA is a result of lipid for every oxidation by a thiobarbituric acid response. The grouping of MDA was determined from the absorbance at $532 \mathrm{~nm}$ (revision finished by subtracting the absorbance at $600 \mathrm{~nm}$ for unspecific turbidity) by utilizing the eradication coefficient of $155 \mathrm{mM}^{-1} \mathrm{~cm}^{-1}$.

\section{Electrolyte leakage}

Leaf pieces of $1 \mathrm{~g}$ were used with $10 \mathrm{ml}$ deionized water in a flask at that point stored at $30^{\circ} \mathrm{C}$ for $24 \mathrm{~h}$ along with vibration. The conductivity of the solution was measured by a conductivity meter $(\mathrm{C} 1)$. The samples were autoclaved for $10 \mathrm{~min}$, cooled to $25^{\circ} \mathrm{C}$; then their conductivity was measured again (C2). The percentage of electrolyte leakage was calculated as follows, EC $(\%)=(\mathrm{C} 1 / \mathrm{C} 2) \times$ 100, as per SHANAHAN et al. (1990).

\section{Proline concentration}

Extraction and estimation of proline-directed by the strategies described by BATES et al. (1973). New leaf, $5.0 \mathrm{~g}$ per test, in a mixture in $10 \mathrm{ml}$ of $3 \%(\mathrm{w} / \mathrm{v})$ fluid sulfosalicylic acid, and the mix strained through a Whatman No. 2. In a test tube, $2 \mathrm{ml}$ of the filtrate was blended with $2 \mathrm{ml}$ ninhydrin and $2 \mathrm{ml}$ glacial acetic acid and brooded in a $100{ }^{\circ} \mathrm{C}$ water bath for one hour. The response blend ended by putting in an ice bath, separated with $4 \mathrm{ml}$ toluene, and the chromophore stage suctioned from the liquid phase. The absorbance perused at $520 \mathrm{~nm}$, utilizing a spectrophotometer.

\section{Minerals concentration}

To determine the mineral concentration, the method of Cresser and Parsons (1979) was applied. The solution wound up transparent and utilized for conclusions of $\mathrm{K}$ and $\mathrm{Na}$ concentrations with an emanation flame photometer. Dried leaves weighing $0.2 \mathrm{~g}$ were used with additional $50 \mathrm{ml} 2 \%$ acetic acid with vibration through $0.5 \mathrm{~h}$ and separated by Whatman No. 1, titrated against $0.01 \mathrm{~N}$ silver nitrate utilizing potassium chromate as an indicator to a bricked endpoint chloride concentration (MiLler,1998).

\section{Data analysis}

The randomized complete block design of the four treatments of the water system was utilized to explore the findings. Test information of an examination of fluctuation (ANOVA) methodology utilizing Tukey's multiple comparison tests was performed at $\alpha \leq 0.05$, and a dendrogram of hierarchical clustering analysis among four treatments and their effects on the parameters of the leaf were performed using the statistical program, IBM SPSS (Ver. 23.0).

\section{Results}

\section{Growth parameters}

Changes were observed in the vegetative growth in terms of plant height and the number of leaves, in addition to the chlorophyll and relative water content under the influence of different irrigation salinity degrees and periods (Fig. 1). Irrigation of date palm offshoots with the freshwater of low electrical conductivity $\left(1.5 \mathrm{dS} \mathrm{m}^{-1}\right)$ every four days (control) led to a significant increase in plant height, the number of leaves, chlorophyll, and relative water content. In comparison, the same measurements decreased significantly, using saltwater with high EC $10 \mathrm{dS} \mathrm{m}^{-1}$ and spaced periods of 7 or 14 days (W2 and W3), except for irrigation with a period of 4 days with saltwater (W1), which differed significantly relative to the other treatments. The effect of saline water irrigation treatments compared with the control treatment in low plant growth is W3 > $\mathrm{W} 2>\mathrm{W} 1$.

\section{Oxidative and antioxidative content}

The different periods of irrigation cycles with groundwater showed significant differences in hydrogen peroxide, MDA, electrolyte leakage, and proline (Fig. 2). Irrigation with saltwater on a 14-day cycle (W3) significantly increased hydrogen peroxide, MDA, electrolyte leakage, and proline. Proline under the influence of irrigation with saltwater did not change dramatically, while proline differed significantly relative to the control treatment, which was substantially lower than other treatments. MDA content of saltwater irrigation every four days (W1) did not differ significantly from the control treatment, while 
MDA differed significantly relative to other treatments of saltwater.

\section{Minerals concentration}

Figure 3 shows the effect of irrigation treatments with freshwater and saltwater on the intensity of sodium, chloride, potassium, and $\mathrm{Na} / \mathrm{K}$ ratio in the leaves. The treatment of irrigation with freshwater decreased the concentration of sodium and chloride significantly, compared with saltwater treatments. Saltwater treatments differed considerably in the level of sodium and chloride in the leaves. The treatment of saltwater every four days significantly reduced sodium concentration compared to other salinity treatments. Whereas, the treatment of

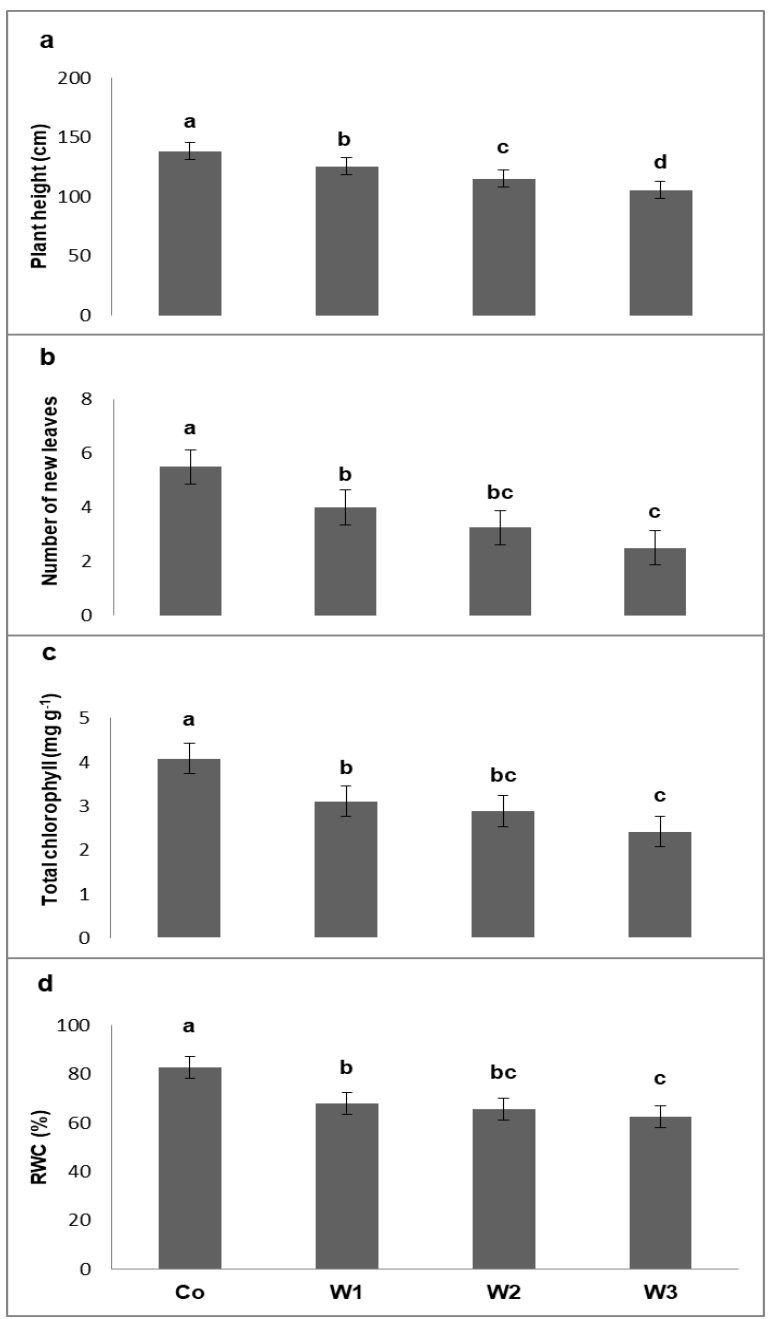

Fig. 1. Impact of different water system cycles with well water irrigation on plant height (a), Number of new leaves (b), Total chlorophyll (c), Relative water content (d) of offshoots date palm Sayer cultivar. (Co) control irrigation with freshwater (EC $1.5 \mathrm{dS} \mathrm{m}^{-1}$ ) every four days. (W1) Irrigation with groundwater $\left(10 \mathrm{dS} \mathrm{m}^{-1}\right)$ every four days. (W2) Irrigation with groundwater every week. (W3) Irrigation with groundwater every two weeks. Results are means $\pm \mathrm{SD}(\mathrm{n}=5)$, and distinctive letters demonstrate significant differences (Tukey's test, $P \leq 0.05$ ).

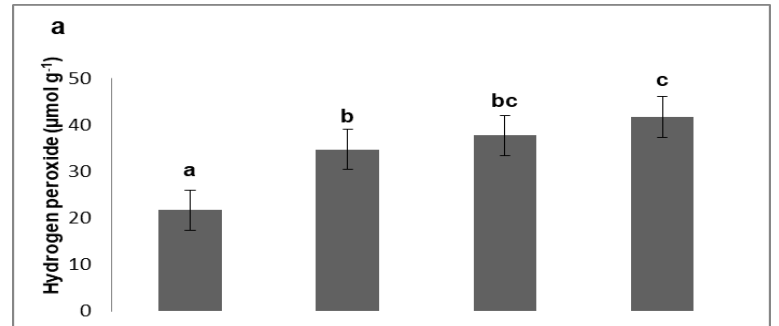

b

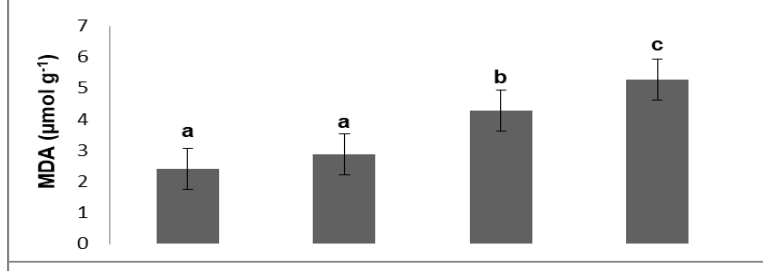

c

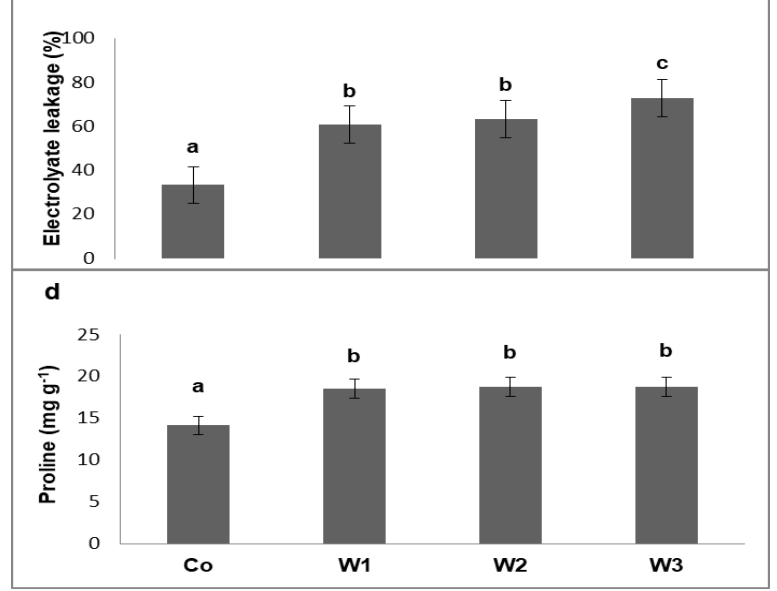

Fig. 2. Impact of different water system cycles with well water irrigation on hydrogen peroxide (a), Malondialdehyde (MDA) (b), Electrolyte leakage (c), Proline (d) of offshoots date palm Sayer cultivar. (Co) control irrigation with freshwater (EC $1.5 \mathrm{dS} \mathrm{m}^{-1}$ ) every four days. (W1) Irrigation with groundwater $\left(10 \mathrm{dS} \mathrm{m}^{-1}\right)$ every four days. (W2)

Irrigation with groundwater every week. (W3) Irrigation with groundwater every two weeks. Results are means \pm SD $(\mathrm{n}=5)$, and distinctive letters demonstrate significant differences (Tukey>s test, $P \leq 0.05$ ).

irrigation with saltwater every four days did not differ significantly with the treatment of salt water every seven days in the concentration of chloride.

Potassium increased significantly in freshwater treatment compared to salinity treatments. The salinity treatments did not differ significantly in the potassium leaf concentration. The percentage of $\mathrm{Na} / \mathrm{K}$ decreased significantly in the freshwater treatment. Salinity treatments every four days did not vary significantly with the treatment of irrigation every seven days in the $\mathrm{Na} / \mathrm{K}$ ratio. In comparison, irrigation application with saltwater every four days and every seven days significantly decreased the $\mathrm{Na} / \mathrm{K}$ ratio of both treatments as compared to the irrigation treatment every 14 days. 


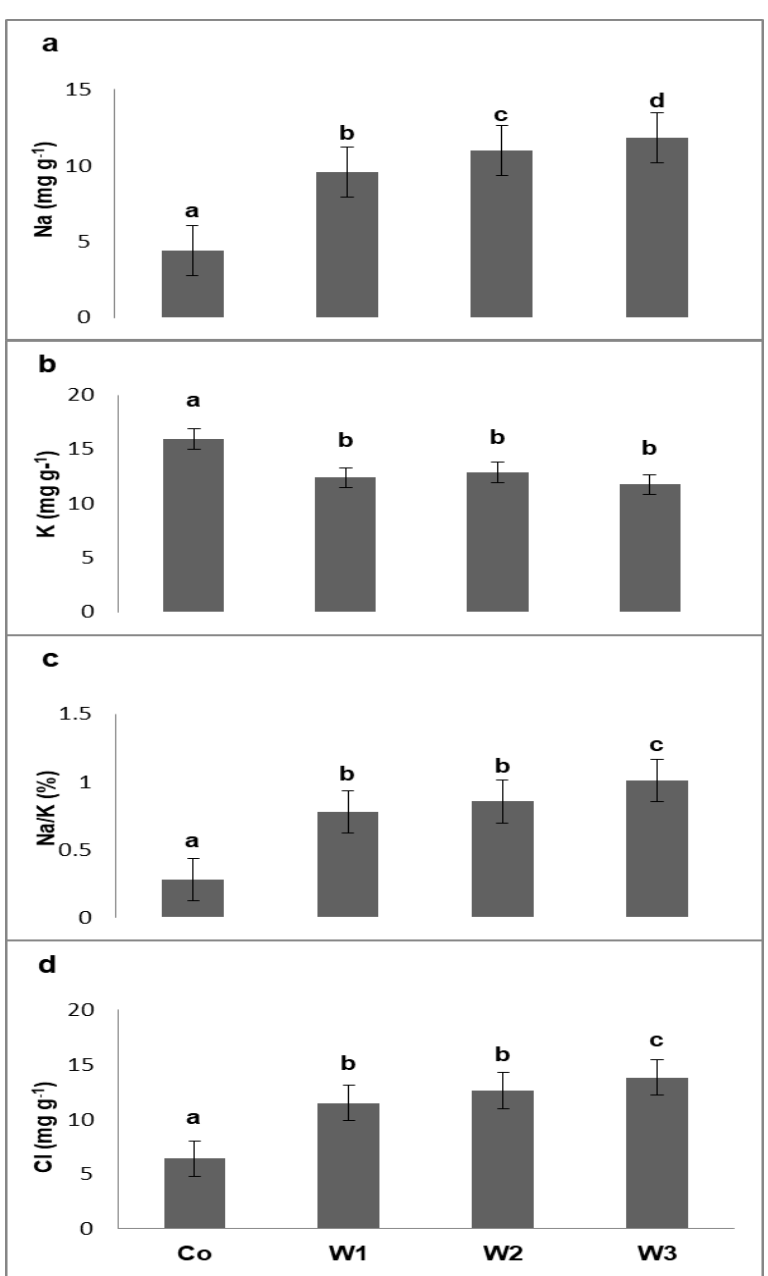

Fig. 3. Impact of different water system cycles with well water irrigation on $\mathrm{Na}$ concentration (a), $\mathrm{K}$ concentration (b),

$\mathrm{Na} / \mathrm{K}$ ratio (c) and chloride concentration (d) of offshoots date palm Sayer cultivar. (Co) control irrigation with freshwater (EC $1.5 \mathrm{dS} \mathrm{m}^{-1}$ ) every four days. (W1) Irrigation with groundwater $\left(10 \mathrm{dS} \mathrm{m}^{-1}\right)$ every four days. (W2)

Irrigation with groundwater every week. (W3) Irrigation with groundwater every two weeks. Results are means $\pm \mathrm{SD}(\mathrm{n}=5)$, and distinctive letters demonstrate significant differences (Tukey>s test, $P \leq 0.05$ ).

\section{Cluster analysis of groundwater treatments}

Hierarchical cluster analysis of groundwater irrigation represented by treatments and their effects on the parameters of the leaf is shown in Figure 4. The analysis showed two distinct clusters. The first group included irrigation with fresh water $\left(1.5 \mathrm{dS} \mathrm{m}^{-1}\right)$ every four days $(\mathrm{Co})$ only. In this first group, the dissimilarity between the treatments is illustrated by the influence of freshwater. While the second group included irrigation with groundwater every four days (W1), irrigation with groundwater every week (W2), and irrigation with groundwater every two weeks (W3), which showed the similarity between the treatments of W1 and W2 in the subgroup. Whereas treatment of W3 shows the most detrimental effect on growth indices and chemical properties of offshoots.

\section{Discussion}

The use of high-quality water with low electrical conductivity of $1-2 \mathrm{dS} \mathrm{m}^{-1}$ is automatically consistent with the growth of the plant and an increase in production. However, the availability of this type of water in quantities appropriate for the growth and production of the date palm is not available in most countries of date palm cultivation. Therefore, the use of available and high saltwater usually depends on the variety of salinity tolerance. The Sayer cultivar used in this experiment exhibited a medium degree of salt tolerance (SHAREEF et al., 2017) to give a moderate indication of the effects of the expansion of date palm cultivation under conditions similar to the experiment.

The salt tolerance mechanism in date palm is still in the hypothesis stage, although there are many studies about it (DJIBRIL et al., 2005; ALJUBURI et al., 2007; JASIM et al., 2016; Allbed et al., 2017; AlDHEBIANI et al., 2017; ShareEF, 2020). However, previous researchers assumed that salinity affects two fundamental processes in date palm survival: water potential changes and ionic concentration changes. Initial exposure to salinity causes water stress, which leads to reduced leaf expansion. When long-term exposures to salinity occur, ion stress leads to premature aging of fully developed leaves. Salinity damage to plants passes through three consecutive states: reducing the osmotic potential of the plant and collecting sodium and chloride in the tissue of the plant, through an imbalance in the absorption of nutrients (EFIMOva et al., 2014). The salt tolerance mechanism works to modify osmotic stress, expulsion sodium or chloride, and accumulation of osmolyte compatible (AlDHEBIANi et al., 2017). Some date palm varieties can grow near the seashore, so date palm can have a rare mechanism that they do not have except for halophytic plants (YAISH and KUMAR, 2015). The effect of cycle of irrigation periods, despite the high salinity level on ongoing growth attributed to the fact that the most influential environmental factor on date palm growth, is drought stress. Date palm offshoots (juvenile phase) do not have deep roots in the soil that can supply water from groundwater, as happens to adult palms (SHAREEF et al., 2017).

However, the increase in chlorophyll content and RWC in the leaves (Fig. 1) attributed to the availability of water leads to the adaptation of the plants to salinity and, consequently, the repair of photosynthesis systems (ÇELIK and ATAK, 2012). The plant adapts to salt stress through the maintenance and protection of the photosynthesis system in the presence of high concentrations of proline (Fig. 2 d). These results are consistent with HAMAD et al. (2015), who found that long term irrigation with very high EC of irrigation water ( 8 and $12 \mathrm{dS} \mathrm{m}^{-1}$ ) led to slow growth of the date palm.

Date palm enhances the production of amino acid proline, which acts as a powerful solution, a metal chelate, an antioxidant, and a signal molecule during certain abiotic stress conditions (YAISH, 2015). Proline is an antioxidant and an osmolyte agent that protects the photosynthesis system against oxidative processes (HASANUZZAMAN et al., 2013). Low drought stress during the continued use 


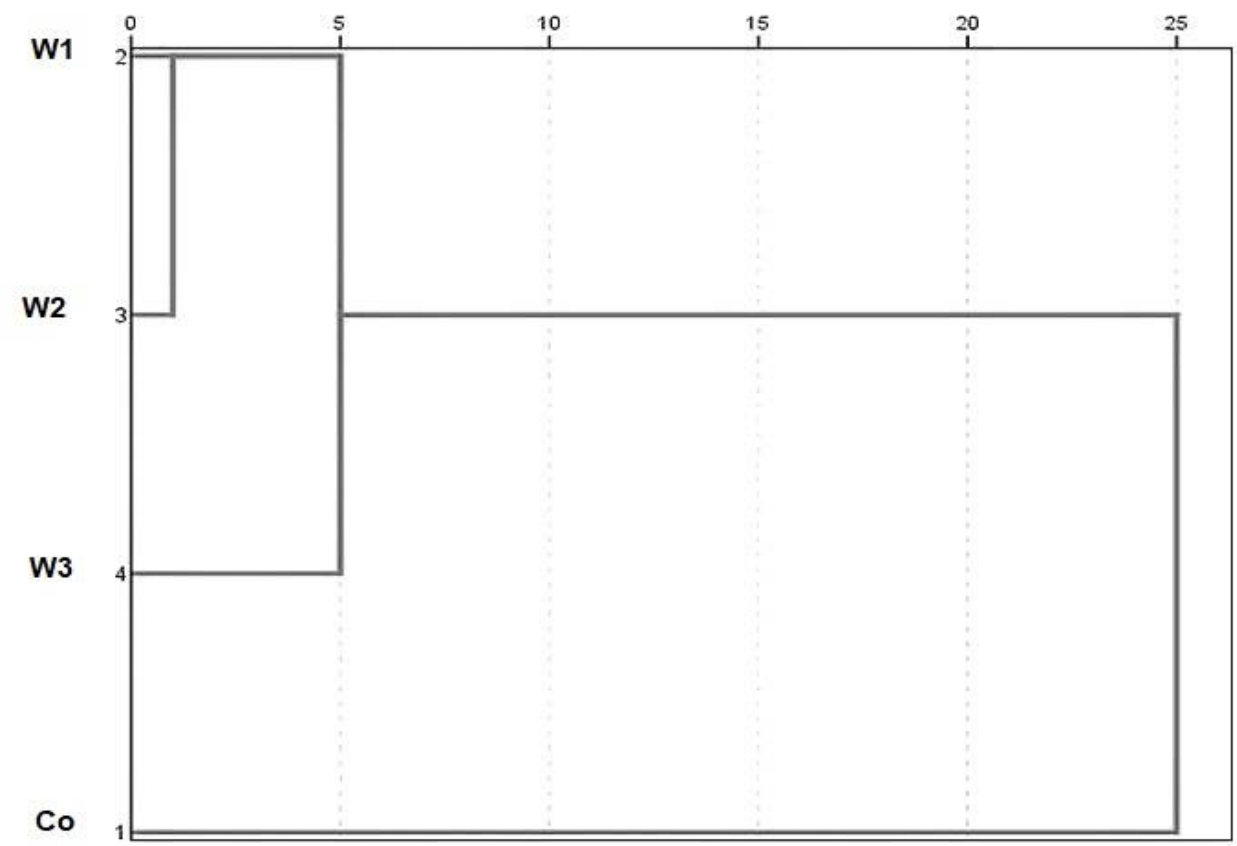

Fig. 4. Dendrogram of hierarchical clustering of leaves of date palm offshoot under different groundwater irrigation periods by using all parameters as an indicator. (Co) control irrigation with freshwater (EC $1.5 \mathrm{dS} \mathrm{m}^{-1}$ ) every four days. (W1) Irrigation with groundwater $\left(10 \mathrm{dS} \mathrm{m}^{-1}\right)$ every four days. (W2) Irrigation with groundwater every week. (W3) Irrigation with groundwater every two weeks.

of groundwater at frequent intervals improves the water content of the plant. Moreover, the adaptation to high salinity for a long time leads to a gradual recovery of the plant (Acosta-Motos et al., 2017). The reduction of hydrogen peroxide by high regulation of the antioxidant compounds led to the recovery of the plant tissues, especially cell walls and the plasma membranes (NIU and LIAO, 2016). Under salinity, MDA content increases as one of the indicators of oxidative stress occurrence and evaluation of cell membrane instability (ABDUL KHALIQ et al., 2015). Often, plants use the defensive catalysts of antioxidants to adapt to saline stress, which prompts oxidative cross-stress (ABDELGAWAD et al., 2016; LIN et al., 2018). Electrolyte leakage decreased under four days of irrigation, thus increasing the stability of these membranes, compared to other applications that did not reduce this oxidative damage.

Roots of date palm contain selective channels, which enhance the absorption of nutrients and the expulsion of the harmful elements under the impact of salinity (ALTURKI, 2018). The availability of water in excess quantities around the root zone helps leach the salts, reducing salinity concentrations. These results apply to the findings of ALMuAINI et al. (2019). Moreover, when the effect of stress is reduced, even if low in proportion, roots recover their capacity to initiate the specific channels and improve the selective channels, subsequently enhancing absorption of the potassium element and decreasing the $\mathrm{Na} / \mathrm{K}$ ratio (JASIM et al., 2016; SHAREEF et al., 2019).
The cluster analysis of the treatments showed the uniqueness of the treatment of irrigation with freshwater in increasing plant growth and moderation of chemical properties, different from the effect of saltwater, which showed the negative impact on plant growth. Nevertheless, the cluster analysis shows the importance of increasing the cycle of irrigations per plant in the efficiency of adaptation to stressful environmental conditions. The availability of saltwater, regardless of its suitability for date palm growth, can reduce the impact of other environmental factors such as high temperature and drought. Consequently, the best applications for saltwater are irrigation every four days under the influence of extreme environmental conditions.

\section{Conclusion}

Date palm cv. Sayer has a tremendous salt-tolerant mechanism and that can endure the surrounding environmental conditions, especially salinity. The use of water wells in irrigation with affinity irrigation intervals is the best among most of the solutions possible in the current terms of drought and thermal retention. Date palm cv. Sayer can survive under these conditions and improve the desert environment, which promotes the exploitation of arid deserts to grow date palm using groundwater. This study reveals the importance of using saline water, which is usually available in desert areas or near the sea, in the growth of date palm to reduce water consumption in agriculture. 


\section{Acknowledgement}

Authors are grateful to Professor Dennis V. Johnson of Cincinnati, Ohio, USA, for critical review and editorial enhancement of this manuscript.

\section{References}

AbBas, M.F., Jasim, A.M., SHAREEF, H.J., 2015. Role of sulphur in salinity tolerance of date palm (Phoenix dactylifera L.) offshoots cvs. Berhi and Sayer. International Journal of Agricultural and Food Science, 5: 92-97.

Abdelgawad, H., Zinta, G., Hegab, M.M., Pandey, R., Asard, H., Abuelsoud, W., 2016. High salinity induces different oxidative stress and antioxidant responses in maize seedlings organs. Frontiers in Plant Science, 7: 276. https://doi.org/10.3389/fpls.2016.00276

Abdul Khaliq, A., Zia-Ul-Haq, M., Ali, F., Aslam, F., Matloob, A., Navab, A., Hussain, S., 2015. Salinity tolerance in wheat cultivars is related to enhanced activities of enzymatic antioxidants and reduced lipid peroxidation. Clean - Soil, Air, Water, 43: 1248-1258. https://doi.org/10.1002/clen.201400854

Acosta-Motos, J.R., Ortuño, M.F., Bernal-Vicente, A., Diaz-Vivancos, P., Sanchez-Blanco, M.J., Hernandez, J.A., 2017. Plant responses to salt stress: adaptive mechanisms. Agronomy, 7: 18. https://doi. org/10.3390/agronomy7010018

Al Kharusi, L., Al Yahyai, R., Yaish, M.W., 2019. Antioxidant response to salinity in salt-tolerant and saltsusceptible cultivars of date palm. Agriculture, 9: 8 . https://doi.org/10.3390/agriculture9010008

Al Kharusi, L., Assaha, D.V.M., Al-Yahyai, R., Yaish, M.W., 2017. Screening of date palm (Phoenix dactylifera L.) cultivars for salinity tolerance. Forests, 8: 136. https:// doi.org/10.3390/f8040136

Al-Muaini, A., Green, S., Dakheel, A., Abdullah, A.H., Abou Dahr, W.A., Dixon, S., Kemp, P., Clothier, B., 2019. Irrigation management with saline groundwater of a date palm cultivar in the hyper-arid United Arab Emirates. Agricultural Water Management, 211: 123131. https://doi.org/10.1016/j.agwat.2018.09.042

Al Omron, A.M., El-Maghraby, S.E., NadeEm, M.E.A., El-Eter, A.M., Al-Mohani, H., 2012. Long term effect of irrigation with the treated sewage effluent on some soil properties of Al-Hassa Governorate, Saudi Arabia. Journal of the Saudi Society of Agricultural Sciences, 11: 15-18. https://doi.org/10.1016/j.jssas.2011.04.004

Aldhebiani, A.Y., Metwali, E.M.R., Soliman, H.I.A., HowlaDAR, S.M., 2017. Response of different date palm cultivars to salinity and osmotic stresses using tissue culture technique. International Journal of Agriculture and Biology, 17: 12-21. https://doi.org/10.17957/ $\mathrm{IJAB} / 15.0674$

Aljuburi, H.J., Maroff, A., Wafi, M., 2007. The growth and mineral composition of Hatamy date palm seedlings as affected by sea water and growth regulators. Acta Horticulturae, 736: 161-164. https://doi.org/10.17660/ ActaHortic.2007.736.13
Allbed, A., Kumar, L., Shabani, F., 2017. Climate change impacts on date palm cultivation in Saudi Arabia. Journal of Agricultural Science, 155: 1203-1218. https://doi. org/10.1017/S0021859617000260

Alrasbi, S.A.R., Hussain, N., Schmeisky, H., 2010. Evaluation of the growth of date palm seedlings irrigated with saline water in the sultanate of Oman. Acta Horticulturae, 882: 233-246.

AltURKI, S., 2018. Effect of $\mathrm{NaCl}$ on growth and development of in vitro plants of date palm (Phoenix dactylifera L.) Khainazi cultivar. Asian Journal of Plant Sciences, 17: 120-128. https://doi.org/10.3923/ajps.2018.120.128

Bates, L. S., Waldren, R. P., Teare, I.D.R., 1973. Determination of free proline for water stress studies. Plant and Soil, 39: 205-207.

Ben-Gal, A., Ityel, E., Dudley, L., Cohen, S., Yermiyahu, U., Presnov, E., Zigmond, L., Shani, U., 2008. Effect of irrigation water salinity on transpiration and on leaching requirements: a case study for bell peppers. Agricultural Water Management, 95: 587-597. https:// doi.org/10.1016/j.agwat.2007.12.008

Çelik, Ö., Аtak, Ç., 2012. The effect of salt stress on antioxidative enzymes and proline content of two Turkish tobacco varieties. Turkish Journal of Biology, 36: 339356. https://doi.org/10.3906/biy-1108-11

Cresser, M.S., Parsons, J., 1979. Sulphuric - perchloric acid digestion of plant material for the determination of nitrogen, phosphorus, potassium, calcium, and magnesium. Analytica Chimica Acta, 109: 431-436.

Duibril, S., Ould, K.M., Diaga, D., Diégane, D., Abaye, B.F., Maurice, S., Alain, B., 2005. Growth and development of date palm (Phoenix dactylifera L.) seedlings under drought and salinity stresses. African Journal of Biotechnology, 4: 968-972.

Efimova, M. V., SavchuK, A.L., Hasan, J.A.K., Litvinovskaya, R.P., Khripach, V.A., Kholodova, V.P., KuZnetsov, V.V., 2014. Physiological mechanisms of enhancing salt tolerance of oilseed rape plants with brassinosteroids. Russian Journal of Plant Physiology, 61: 733-743. https://doi.org/10.1134/S1021443714060053

Hamad, I., Abdelgawad, H., Al Jaouni, S., Zinta, G., Asard, H., Hassan, S., Hegab, M., Hagagy, N., Selim, S., 2015. Metabolic analysis of various date palm fruit (Phoenix dactylifera L.) cultivars from Saudi Arabia to assess their nutritional quality. Molecules, 20: 13620 13641. https://doi.org/10.3390/molecules200813620

Hasanuzzaman, M., Nahar, K., Fujita, M., 2013. Plant response to salt stress and role of exogenous protectants to mitigate salt-induced damages. In Ahmad, P., AHmaD, P., Azooz, M.M., Prasad, M.N.V.(eds). Ecophysiology and responses of plants under salt stress. New York: Springer. 510 p. https://doi.org/10.1007/978-1-4614-4747-4

Ismail, S.M., Al-Qurashi, A.D., AwaD, M.A., 2014. Optimization of irrigation water use, yield, and quality of "Nabbut-Saif" date palm under dry land conditions. Irrigation and Drainage, 63: 29-37. https://doi. org/10.1002/ird.1823

Jasim, A.M., Abbas, M.F., Shareef, H.J., 2016. Calcium application mitigates salt stress in date palm (Phoenix dactylifera L.) offshoots cultivars of Berhi and Sayer. 
Acta Agriculturae Slovenica, 107: 103-112. https://doi. org/10.14720/aas.2016.107.1.11

MilleR, R.O., 1998. Extractable chloride, nitrate, orthophosphate, potassium, and sulfate-sulfuric plant tissue: $2 \%$ acetic and extraction. In KaLRA, Y.P. Handbook of reference methods for plant analysis. Boca Raton: CRC Press, p. 115-118.

Lichtenthaler, H.K., Wellburn, A.R., 1983. Determinations of total carotenoids and chlorophylls $\mathrm{a}$ and $\mathrm{b}$ of leaf extracts in different solvents. Biochemical Society Transactions, 11: 591-592.

Lin, J.S., KuO, C.C., Yang, I.C., Tsai, W.A., Shen, Y.H., Lin, C.C., Liang, Y.C., LI, Y.C., KuO, Y.W., King, Y.C., LaI, H.M., JENG, S.T., 2018. MicroRNA160 modulates plant development and heat shock protein gene expression to mediate heat tolerance in Arabidopsis. Frontiers in Plant Science, 9: 68. https://doi.org/10.3389/fpls.2018.00068

Madhava Rao, K.V., Sresty, T.V.S., 2000. Antioxidative parameters in the seedlings of pigeonpea (Cajanus cajan L. Millspaugh) in response to $\mathrm{Zn}$ and $\mathrm{Ni}$ stresses. Plant Science, 157: 113-128.

NiU, L., LiaO, W., 2016. Hydrogen peroxide signaling in plant development and abiotic responses: Crosstalk with nitric oxide and calcium. Frontiers in Plant Science, 7: art. 230. https://doi.org/10.3389/fpls.2016.00230

Pal, L.E.R., Preez, C.D., Strydom, M., Rensburg, L., BENNIE, A., 2010. Effect of irrigation on soil salinity profiles along the lower Vaal River, South Africa. Water Resources Research, 33: 473-478.

Ramoliya, P.J., Pandey, A.N., 2003. Soil salinity and water status affect growth of Phoenix dactylifera seedlings. New Zealand Journal of Crop and Horticultural Science, 31: 345-353. https://doi.org/10.1080/01140671.2003.95142 70

Shanahan, J.F., Edwards, I.B., Quick, J.S., 1990. Membrane thermostability and heat tolerance of spring wheat. Crop Sciences, 30: 247-251.

SHAREEF, H.J., 2019. Salicylic acid and potassium promote flowering through modulating the hormonal levels and protein pattern of date palm Phoenix dactylifera L. Sayer offshoots. Acta Agriculturae Slovenica, 114: 231-238. https://doi.org/10.14720/aas.2019.114.2.8

SHAREEF, H.J., 2020. Organic fertilizer modulates IAA and ABA levels and biochemical reactions of date palm Phoenix dactylifera L. Hillawi cultivar under salinity conditions. Asian Journal of Agriculture and Biology, 8: 24-30. https://doi.org/10.35495/ajab.2019.02.062

Shareef, H.J., Abdi, G., Fahad, S., 2020. Change in photosynthetic pigments of date palm offshoots under abiotic stress factors. Folia Oecologica, 47: 45-51. https://doi.org/10.2478/foecol-2020-0006

Shareef, H.J., Jasim A.M., AbBas, M.F., 2017. Molecular analysis of anti-salinity compounds on date palm offshoots (Phoenix dactylifera L.) cultivars using RAPD. Journal of Environment Science, 6: 61-71.

Sharif, A.O., Sanduk, M., Taleb, H.M., 2010. The date palm and its role in reducing soil salinity and global warming. In Zaid, A., Alhadrami, G.A. (eds). Proceedings of the fourth international date palm conference. Abu Dhabi, United Arab Emirates, March 15-17, 2010. Acta Horticulturae, 882. Leuven: ISHS, pp. 59-64.

Yaish, M.W., Kumar, P.P., 2015. Salt tolerance research in date palm tree (Phoenix dactylifera L.), past, present, and future perspectives. Frontiers in Plant Science, 6: 1-5. https://doi.org/10.3389/fpls.2015.00348

Yu, C.W., Murphy, T., Lin, C., 2003. Hydrogen peroxideinduces chilling tolerance in mung beans mediated through ABA-independent glutathione accumulation. Functional Plant Biology, 30: 955-963.

Zhang, J., Xu, X., Lei, J., Sun, S., Fan, J., Li, S., Gu, F., Qiu, Y., XU, B., 2008. The salt accumulation at the shifting aeolian sandy soil surface with high salinity groundwater drip irrigation in the hinterland of the Taklimakan Desert. Chinese Science Bulletin, 53: 63-70. https://doi. org/10.1007/s11434-008-6006-3

Received March 24, 2020 Accepted July 23, 2020 